\title{
Correlation between cytotoxicity in cancer cells and free radical-scavenging activity: In vitro evaluation of 57 medicinal and edible plant extracts
}

\author{
MAREI SAMMAR ${ }^{1}$, BASHEER ABU-FARICH ${ }^{2}$, IBRAHIM RAYAN $^{2}$, MIZIED FALAH $^{3,4^{*}}$ and ANWAR RAYAN A. $^{2 *}$ \\ ${ }^{1}$ Ephraim Katzir Department of Biotechnology Engineering, ORT Braude College, Karmiel 2161002; \\ ${ }^{2}$ Drug Discovery Informatics Lab, QRC-Qasemi Research Center, Faculty of Science, Al-Qasemi Academic College, \\ Baka EL-Garbiah 30100; ${ }^{3}$ Research Institute, Galilee Medical Center, 22100 Nahariya; ${ }^{4}$ Faculty of Medicine in The \\ Galilee, Bar-Ilan University, Safed 1311502; ${ }^{5}$ Institute of Applied Research-Galilee Society, Shefa-Amr 20200, Israel
}

Received December 9, 2018; Accepted August 6, 2019

DOI: $10.3892 / \mathrm{ol} .2019 .11054$

\begin{abstract}
Cancer is a complex interaction among multiple signaling pathways involving a variety of target molecules. Cancer causes morbidity and mortality in millions of people worldwide, and due to its prevalence, the discovery of novel anticancer drugs is urgently required. Nature is considered an important source of the discovery of anticancer treatments, and many of the cytotoxic medicines in clinics today are derived from plants and other natural sources. Reactive oxygen species (ROS) induce a variety of human cancers, and antioxidants or scavengers are used to counteract them. The current study reports on the screening of extracts from 57 plants that are used in the galilee district as a food and/or for traditional medicine. Investigating the free radical scavenging capacity and these plants, and their cytotoxicity, may prove helpful to high-throughput screening projects that use antioxidants and cytotoxic natural products. The current study assessed the correlation between free radical scavenging and cytotoxicity. Correlational analysis is important for increasing the efficiency of the screening process. In the present study, free radical scavenging was assessed using a DPPH assay, while cytotoxicity was measured using a XTT assay. A total of 9 extracts were indicated to exhibit $\mathrm{EC}_{50}$ values $<250 \mu \mathrm{g} / \mathrm{ml}$, and 4 others exhibited a high antioxidant content, with $\mathrm{EC}_{50}$ values, for free radical scavenging, of $<0.5 \mu \mathrm{g} / \mathrm{ml}$. An in-depth analysis of the results revealed that the extracts of plants that exhibit an $\mathrm{EC}_{50}$ of free radical scavenging $\leq 10 \mu \mathrm{g} / \mathrm{ml}$ show a degree of enrichment
\end{abstract}

Correspondence to: Professor Anwar Rayan, Drug Discovery Informatics Lab, QRC-Qasemi Research Center, Faculty of Science, Al-Qasemi Academic College, 1 Qasemi Street, Baka EL-Garbiah 30100, Israel

E-mail: a_rayan@qsm.ac.il

${ }^{*}$ Contributed equally

Key words: cytotoxicity, antioxidant, free radical scavenging, medicinal plant, edible plant toward increased cytotoxicity. It is recommended that future studies test the validity of the conclusions of the current study on other cancer cell-lines, and isolate and identify the bioactive agents that are found in the most cytotoxic extracts of plants.

\section{Introduction}

A large variety of plant-based nutrients and phytochemicals consumed by humans has long been considered to be associated with human health, and has even proved to reduce the risk of inflammation (1-3) and illnesses such as diabetes (4), cardiovascular (5), neurodegenerative (6), microbial-related diseases $(7,8)$, and certain types of cancer (9-13). Cancer continues to be a major health challenge, constituting the second-leading cause of death worldwide, despite intensive and extensive research that has revealed much about its biology in last few decades $(14,15)$. In parallel, considerable progress in anti-cancer therapies has been made, allowing the cure of cancer patients and helping to prolong their survival rate. Despite such advances in its early detection, and improvements in treatment and prevention, cancer remains a major challenge in terms of morbidity and mortality. Therefore, enormous scientific and commercial endeavors have been made to discover further anti-cancer agents. In view of this, natural products that have been studied for a long time, have been found to have pharmacologic activity, and have proved to be safe with long-term exposure (16). Some of these plant-extracted products are currently available on the pharmaceutical market as antioxidants or scavengers, and are used to counteract reactive oxygen species (ROS), the triggers for various types of human cancer (17). ROS, produced either endogenously or by exogenous stimuli, can damage DNA, proteins, and lipids, which can lead to the transformation of normal cells into cancer cells through the mutation of key genes (18). Cancer initiation and progression can also occur due to an unbalanced redox equilibrium, an inherent defense system of cells that endogenously generate and scavenge ROS, leading to increased DNA damage, prevention of cell apoptosis, and consequently, to a higher rate of cell survival $(19,20)$. Given this, the excessive production of intracellular ROS has been targeted by 
antioxidants as therapeutic agents to prevent or suppress the development or propagation of cancer cells (21). Many plants have been found to have significant ROS-scavenging activity (antioxidant activity), which is associated with cytotoxicity (antiproliferative activity) toward cancer cells, and thus could be used as therapeutic and preventive agents (22-24). This association is clear in the observations that curcumin, a natural polyphenol derived from the rhizome of turmeric, and quercetin, an anti-oxidant derived from fruits and vegetables, have been shown to have potent free radical-scavenging and cytotoxic activity $(25,26)$.

As cancer cells have developed the capability to escape apoptosis through a number of mechanisms-cellular transformation, apoptosis dysregulation, proliferation, migration, angiogenesis, and metastasis. Patients with cancer have been treated and managed by conventional surgery, chemotherapy, or radiotherapy. However, researchers have begun to find encouraging clinical results pointing to the value of plant-based products in cancer treatment, and physicians have started to use these medications. They support, and even strengthen, various systems of the body that are under stress due to chemical toxicity or traumatic events. In contrast to chemotherapy, which often induces a number of undesired toxic side effects, natural therapies, such as the use of plant-derived products, may have the capability to reduce some of these toxicities (27). Plants and other natural products have for a long time been the main source of anti-tumor drug candidates. Many of the anticancer drugs used today, such as vinblastine, vincristine, Paclitaxel, and camptothecin, are based mainly on natural drugs $(14,28)$.

ROS are unstable species that pair up their odd free electrons by attacking healthy cells, causing a loss of cell structure and/or function (29). The impaired cells are key contributors to degenerative diseases such as cancer, inflammation, immune system weakening, liver disease, brain dysfunction, cardiovascular conditions, diabetes, and renal failure (30). Therefore, antioxidants/free radical-scavenging agents are vital to controlling the damaging effect of free radicals in the human body (31). As a result, verifying the type of correlation between free radical-scavenging of plant extracts and their cytotoxicity to cancer cells is an issue of great importance. The purpose of this study is to evaluate the free radical-scavenging of dozens of plant-based extracts, as well as their cytotoxicity to the HepG 2 cell line (liver cancer). To the best of our knowledge to date, the correlation between free radical-scavenging and cytotoxicity has not yet been tested on a large scale nor reported in scientific journal. To explore and possibly verify this correlation, we tested fifty-seven methanolic extracts derived from regional plants that see heavy use as food and as traditional medicines.

Finding the type of correlation between free radical-scavenging of plant extracts and their cytotoxicity could be helpful in high-throughput screening projects that search for cytotoxic natural products. If a positive correlation exists, then, it may not imply that a change in the value of one parameter will cause a change in the value of the other parameter.

\section{Materials and methods}

Materials and cells. All plants that were used in this study were purchased from Al-Alim Ltd. (Medicinal Herb Center) or from the local market (those that are labeled with a symbol ${ }^{\text {a }}$ in Table I). All our research involving wild-type species are not at risk of extinction and not registered in the endangered species flora list. The gallic acid, DPPH, and the solvents were purchased from Sigma. HepG2 liver cancer cell line was purchased from the American Tissue Culture Collection (ATCC; catalog no. HB-8065; passage 05-10). Eagle's minimum essential medium (EMEM), fetal bovine serum, antibiotics, and the XTT kit were purchased from Biological Industries.

Extraction of plants. To perform the extraction, one gram of dried plant material was packed in a tube, soaked with 10 milliliters of methanol, sonicated for $75 \mathrm{~min}$ at $40^{\circ} \mathrm{C}$, and then left in for $3 \mathrm{~h}$ to cool down. After complete extraction, the methanolic extract solution was filtered with Whatman paper, grade 1 , dried under vacuum, weighed, and then dissolved by DMSO at a concentration of $100 \mathrm{mg} / \mathrm{ml}$. The extract was kept at $4^{\circ} \mathrm{C}$ until it was used.

Free radical scavenging (FRS). The FRS of the methanolic extracts of the various plants was measured by microdilution using the DPPH assay protocol, with slight modifications $(32,33)$. The microdilution of DPPH was performed using two-fold serial dilution in $\mathrm{ddH}_{2} \mathrm{O}$. The tests were carried out in 96-well, flat-bottomed plates. $100 \mu \mathrm{l}$ of ethanolic DPPH solution (200 ppm) was added to $100 \mu \mathrm{l}$ of the plant extract at the concentration stated in Table I. The mixture was then shaken and allowed to settle for $30 \mathrm{~min}$ in the dark at room temperature. The absorbance of the solution was measured at $517 \mathrm{~nm}$ and converted into a percentage of FRS using the following equation:

$$
\begin{aligned}
& \text { FRS\% } \left.\% 100 *\left\{1-\left[\left(\mathrm{A}_{\text {sample }}-\mathrm{A}_{\text {blank_1 }}\right)\right) /\left(\mathrm{A}_{\text {control }}-\mathrm{A}_{\text {blank_2 }}\right)\right]\right\} \\
& \text { where } \\
& A_{\text {sample }} \text { is the absorbance of the mixture (of plant extract } \\
& \text { and DPPH), } \\
& A_{\text {blank-1 }} \text { is the absorbance of the plant extract, } \\
& A_{\text {control }} \text { is the absorbance of the ethanolic solution of DPPH, } \\
& \text { and } A_{\text {blank-2 }} \text { is the absorbance of ethanol. }
\end{aligned}
$$

Gallic acid at a concentration of $100 \mu \mathrm{g} / \mathrm{ml}$ was used as a positive control. FRS was expressed in terms of the $\mathrm{EC}_{50}$ (the amount of antioxidant necessary to decrease the initial DPPH absorbance by $50 \%$ ). The $\mathrm{EC}_{50}$ value for each extract was determined by extracting the value from the equation for the linear part of the graph. We substituted $50 \%$ for the $y$ value, while calculating the concentration value of the $x$-axis.

Cell culture and cytotoxicity assay. HepG2 cells were cultured in EMEM medium supplemented with $10 \%$ fetal bovine serum and $100 \mathrm{U} / \mathrm{ml}$ of penicillin streptomycin (Biological Industries). The cells were cultured at $37^{\circ} \mathrm{C}$ in an incubator with $5 \% \mathrm{CO}_{2}$. The cytotoxic effect of the extracts on the cells was assessed using a cell proliferation kit (XTT-based). In short, $2.5 \times 10^{3}$ HepG 2 cells were seeded into each well of a 96-well plate and cultured for $24 \mathrm{~h}$. The cells were treated with various concentrations of plant extract $(0,10$, $20,30,40,50,100,200,300,400$ and $500 \mu \mathrm{g} / \mathrm{ml})$ for $48 \mathrm{~h}$ and then incubated with XTT reagents for $3 \mathrm{~h}$ at $37^{\circ} \mathrm{C}$, and 
Table I. A list of medicinal and edible plants that were used in the current study and their yield of methanolic extraction, $\mathrm{EC}_{50}$ for free radical scavenging, percentage of inhibition at a concentration of $250 \mu \mathrm{g} / \mathrm{ml}$ of plant extract and 4-EC ${ }_{50}$ cytotoxicity for the most active plant.

\begin{tabular}{|c|c|c|c|c|}
\hline $\begin{array}{l}\text { Scientific name } \\
\text { (part of the plant) }\end{array}$ & $\begin{array}{l}\text { The extract } \\
\text { yield }(\%)\end{array}$ & $\begin{array}{l}\mathrm{EC}_{50} \text { of free radical } \\
\text { scavenging }(\mu \mathrm{g} / \mathrm{ml})\end{array}$ & $\begin{array}{c}\% \text { Inhibition at concentrations } \\
\text { of } 250 \mu \mathrm{g} / \mathrm{ml} \text { of }(\%)\end{array}$ & $\begin{array}{c}\mathrm{EC}_{50} \text { of } \\
\text { cytotoxicity }(\mu \mathrm{g} / \mathrm{ml})\end{array}$ \\
\hline Vitis vinifera (leaf) & 6.32 & 4.63 & 13 & \\
\hline Stevia rabaudiana (leaf) & 19.38 & 9.77 & 12 & \\
\hline Rosmarinus officinalis (leaf) & 11.72 & 3.45 & 95 & 131 \\
\hline Rubus idaeus (leaf) & 4.82 & 4.25 & 22 & \\
\hline Punuca granatum (fruit peel) & 38.02 & 87.30 & 49 & \\
\hline Origanum vulgare (leaf) & 10.00 & 1.67 & 90 & 180 \\
\hline Vitex agnus-castus (seeds) & 3.60 & 166.43 & 99 & 42 \\
\hline Thymus vulgaris (leaf) & 11.63 & 1.98 & 33 & \\
\hline Mentha piperita (leaf) & 10.97 & 1.68 & 30 & \\
\hline Melissa officinalis (leaf) & 9.70 & 0.28 & 36 & \\
\hline Urtica urens/pilulifera (leaf) & 7.33 & 220.92 & 0 & \\
\hline Orea europaea (leaf) & 25.20 & 2.98 & 30 & \\
\hline Camelia sinensis (leaf) & 11.26 & 54.2 & 33 & \\
\hline Cynara cardunculus (leaf) & 20.15 & 17.61 & 95 & 152 \\
\hline Foeniculurn vulgare (seeds) & 4.06 & 26.74 & 0 & \\
\hline Petroselinum crispum (leaf) & 18.78 & 282.70 & 0 & \\
\hline Pelargonium spp (leaf) & 11.30 & 2.83 & 53 & \\
\hline Lippia citriodora (leaf) & 8.33 & 4.14 & 92 & 197 \\
\hline Ocimum basilicum (leaf) & 11.22 & 8.73 & 3 & \\
\hline Sumac (ripe fruit) & 30.44 & $<0.5$ & 66 & \\
\hline Zingiber officinale (root) & 4.32 & 81.0 & 95 & 109 \\
\hline Cinnamomum aromaticum (bark) & 4.26 & 1.67 & 100 & 162 \\
\hline Cuminum cyminum (seeds) & 10.14 & 23.90 & 10 & \\
\hline Portulaca oleracea (leaf and stem) & 10.08 & 47.33 & 14 & \\
\hline Centaurea (leaf and stem) & 12.10 & 249.97 & 18 & \\
\hline Scolymus maculatus (leaf and stem) & 3.82 & 259.03 & 0 & \\
\hline Cichorium intybus (leaf) & 15.08 & 83.96 & 0 & \\
\hline Malva $^{a}($ leaf $)$ & 14.77 & $<0.5$ & 0 & \\
\hline Allium cepa (leaf) & 8.15 & 215.20 & 0 & \\
\hline Corchorus olitorius (leaf) & 11.23 & 10.64 & 0 & \\
\hline Gundelia tournefortii ${ }^{a}$ (stem) & 10.44 & 140.79 & 0 & \\
\hline Hyssopus (leaf) & 3.60 & 13.10 & 0 & \\
\hline Green tea (leaf) & 14.73 & 0.38 & 0 & \\
\hline Petroselinum (leaf and stem) & 6.96 & 35.97 & 0 & \\
\hline Thymus capitatus (leaf) & 9.28 & 2.12 & 37 & \\
\hline Foeniculurn vulgare (leaf and stem) & 4.76 & 20.86 & 33 & \\
\hline Melissa officinalis (leaf) & 8.80 & 24.0 & 0 & \\
\hline Petroselium (leaf) & 17.55 & 381.20 & 4 & \\
\hline Laurus nobilis (leaf) & 12.74 & 8.92 & 93 & 182 \\
\hline Salvia officinalis (leaf) & 9.22 & 267.92 & 90 & 142 \\
\hline Cymbopogon citratus (leaf) & 11.54 & 9.80 & 24 & \\
\hline Linum usitatissimum (seeds) & 0.40 & $4,523.5$ & 0 & \\
\hline Avena sativa (seeds) & 22.00 & 635.51 & 1 & \\
\hline Ceratonia siliqua (ripe fruit) & 25.06 & 130.9 & 12 & \\
\hline Origanum syriacum (leaf) & 13.53 & 1.84 & 15 & \\
\hline Camomile (leaf and flowers) & 16.25 & 29.00 & 7 & \\
\hline Salvia hispanica (seeds) & 0.50 & $3,736.5$ & 4 & \\
\hline Crocus $^{a}($ seeds $)$ & 0.96 & 765.2 & 31 & \\
\hline Vitex agnus-castusa (stem + leaf) & 12.00 & 266.51 & 0 & \\
\hline
\end{tabular}


Table I. Continued.

\begin{tabular}{|c|c|c|c|c|}
\hline $\begin{array}{l}\text { Scientific name } \\
\text { (part of the plant) }\end{array}$ & $\begin{array}{l}\text { The extract } \\
\text { yield }(\%)\end{array}$ & $\begin{array}{l}\mathrm{EC}_{50} \text { of free radical } \\
\text { scavenging }(\mu \mathrm{g} / \mathrm{ml})\end{array}$ & $\begin{array}{c}\% \text { Inhibition at concentrations } \\
\text { of } 250 \mu \mathrm{g} / \mathrm{ml} \text { of }(\%)\end{array}$ & $\begin{array}{c}\mathrm{EC}_{50} \text { of } \\
\text { cytotoxicity }(\mu \mathrm{g} / \mathrm{ml})\end{array}$ \\
\hline Marrubium vulgare ${ }^{a}$ (leaf) & 2.56 & 51.3 & 0 & \\
\hline Ficus religiosa ${ }^{a}($ stem $)$ & 4.22 & 215.92 & 23 & \\
\hline Lepidium sativum $^{a}$ (seeds) & 0.84 & $2,529.8$ & 0 & \\
\hline Angelica sylvestris ${ }^{a}$ (leaf) & 10.10 & 2.00 & 3 & \\
\hline Gentianaa (leaf) & 30.76 & 396.03 & 0 & \\
\hline Pelargonium sp..$^{a}$ (stem) & 3.88 & 146.5 & 3 & \\
\hline Eryngium $^{a}($ stem $)$ & 4.32 & 253.31 & 0 & \\
\hline Humulus lupupus ${ }^{a}$ (leaf) & 12.36 & 4.22 & 3 & \\
\hline
\end{tabular}

aPlants purchased at the local market.

absorbance was measured at $450 \mathrm{~nm}$. The mean absorbance of non-treated cells served as the reference value for calculating the percentage of cellular viability. The assay was carried out in triplicate. Culture medium without cells was used as a background control (blank) and was subtracted from the other measurements.

Model assessments. Parameters such as the Matthews correlation coefficient (MCC), accuracy, the precision enrichment factor, and the area under the ROC curve (AUC) were used to assess the quality of the cytotoxicity/free radical-scavenging correlation models.

Equation 1. Matthews correlation coefficient (MCC).

$$
M C C=\frac{(P N)-\left(P f N_{f}\right)}{\sqrt{\left(N+N_{f}\right)(N+P f)\left(P+N_{f}\right)\left(P+P_{f}\right)}}
$$

where

$P, N, P_{f}$ and $N_{f}$ are the numbers of true positive, true negative, false positive, and false negative predictions, respectively. A perfect prediction gives $\mathrm{MCC}=1.0$, while a random performance gives $\mathrm{MCC}=0.0 . \mathrm{MCC}=-1.0$ indicates a completely erroneous prediction.

Equation 2. Accuracy.

Accuracy $=(P+N) /\left(P+N+P_{f}+N_{f}\right)$

Equation 3. Precision.

Precision $=P /\left(P+P_{f}\right)$

Equation 4. Enrichment factor.

$E F=T_{F R S} / T_{R S}$

where

$T_{F R S}$ is the $\%$ of actives when using the FRS threshold criterion, and $T_{R S}$ is the $\%$ of actives by random selection.

Statistical analysis. All statistical analyses were conducted using Excel spreadsheet software (v16.0; Microsoft). The quality of correlation between any two parameters was evaluated using a regression analysis based on the value of the coefficient of determination $\left(\mathrm{R}^{2}\right)$. Reliability decreases with a decrease in the $R^{2}$ value $\left(R^{2}=1\right.$ means completely reliable, while $\mathrm{R}^{2}=0$ means completely unreliable).

\section{Results and Discussion}

Fifty-seven edible medicinal plants were studied by measuring their free radical-scavenging (by DPPH assay) and their cytotoxic activity (by XTT assay). All results are summarized in Table I. The average yield of extraction by methanol was $11.2 \%$, and as shown in Fig. 1, no correlation was detected between the $\%$ of extraction yield and free radical scavenging. However, the four plants that gave a $\%$ of yield of $<1 \%$ (Linum usitatissimum, Salvia hispanica, Lepidium sativum and Crocus) possess the lowest free radical-scavenging activity $\left(\mathrm{EC}_{50}\right.$ values, of 4,523, 3,736, 2,529 and $765 \mu \mathrm{g} / \mathrm{ml}$, respectively). A review of column 3 of Table I reveals that Malva, sumac, Melissa officinalis, and green tea have the highest content of antioxidants, with $\mathrm{EC}_{50}$ values of free radical-scavenging of $<0.5 \mu \mathrm{g} / \mathrm{ml}$. Cytotoxicity was first verified by screening all extracts for their activity, using one concentration of $250 \mu \mathrm{g} / \mathrm{ml}$; column 4 depicts the $\%$ of inhibition at this concentration. The extracts that gave a $\%$ of inhibition above $90 \%$ were tested in the second round at lower concentrations in dose response manner to extract their $\mathrm{EC}_{50}$ values. The results are summarized in column 5 . Nine extracts were found to have $\mathrm{EC}_{50}$ values of $<250 \mu \mathrm{g} / \mathrm{ml}$ (Rosmarinus officinalis, Origanum vulgare, Vitex agnus-castus, Cynara cardunculus, Lippia citriodora, Zingiber officinale, Cinnamomum aromaticum, Laurus nobilis, and Salvia officinalis). Their $\mathrm{EC}_{50}$ values are $131,180,42,152,197,109,162,182$ and $142 \mu \mathrm{g} / \mathrm{ml}$, respectively. Three other extracts [Punuca granatum (fruit peel), Pelargonium spp (leaf), Sumac (ripe fruit)] have $\mathrm{EC}_{50}$ values close to $250 \mu \mathrm{g} / \mathrm{ml}$, where treatment with $250 \mu \mathrm{g} / \mathrm{ml}$ inhibit viability of liver cancer cells by 49,53 and $66 \%$, respectively.

Rules-based analysis using Matthew's correlation coefficient (MCC) scores and enrichment factors as criteria for the evaluation of the models' efficiency revealed that the plant extracts whose $\mathrm{EC}_{50}$ for free radical scavenging $\leq 10 \mu \mathrm{g} / \mathrm{ml}$ showed some degree of enrichment toward more cytotoxicity (Table II). The values for the enrichment factor, the MCC, accuracy, and precision are 2.6, 0.28, 0.67 and 0.5 , respectively. 
Table II. MCC scores and enrichment factors were utilized as criteria for evaluating the models. All calculations are based on the assumption that a $\%$ of cytotoxicity $\geq 30 \%$, at a concentration of $250 \mu \mathrm{g} / \mathrm{ml}$ of plant extract, is considered active (a true positive); otherwise, it is considered inactive. One third of the tested plants (nineteen extracts) showed activity $\geq 30 \%$ cytotoxicity.

$\mathrm{EC}_{50}$ cutoff of FRS ( $\left.\leq\right)$

\begin{tabular}{lcccc}
\cline { 2 - 5 } Criteria & $10 \mu \mathrm{g} / \mathrm{ml}$ & $50 \mu \mathrm{g} / \mathrm{ml}$ & $250 \mu \mathrm{g} / \mathrm{ml}$ & No limit \\
\hline No. active plants (true positives) $^{\mathrm{a}}$ & 11 & 13 & 17 & 19 \\
No. inactive plants (false positives) $^{\mathrm{b}}$ & 11 & 19 & 28 & 38 \\
No. inactive plants (true negatives) $^{\mathrm{c}}$ & 27 & 19 & 10 & - \\
No. active plants (false negatives) $^{\mathrm{d}}$ & 8 & 6 & 2 & - \\
Precision $_{\text {Accuracy }}$ & 0.5 & 0.41 & 0.38 & 0.34 \\
Enrichment factor & 0.67 & 0.56 & 0.47 & 0.34 \\
MCC & 1.5 & 1.22 & 1.13 & 1.0 \\
\end{tabular}

${ }^{a}$ Number of plant extracts that have an $\mathrm{EC}_{50}$ of FRS less than the indicated threshold and $\geq 30 \%$ cytotoxicity against HepG2 cancerous cells

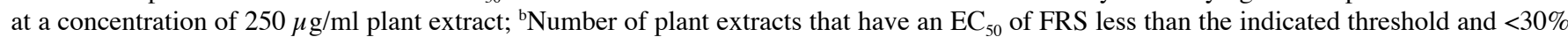
cytotoxicity against HepG2 cancerous cells at a concentration of $250 \mu \mathrm{g} / \mathrm{ml}$ plant extract; ${ }^{\mathrm{C}}$ Number of plant extracts that have an $\mathrm{EC}_{50}$ of FRS greater than the indicated threshold and $<30 \%$ cytotoxicity against HepG2 cancerous cells at a concentration of $250 \mu \mathrm{g} / \mathrm{ml} \mathrm{plant}$ extract; ${ }^{\mathrm{d}}$ Number of plant extracts that have an $\mathrm{EC}_{50}$ of FRS greater than the indicated threshold and $\geq 30 \%$ cytotoxicity against HepG 2 cancerous cells at a concentration of $250 \mu \mathrm{g} / \mathrm{ml}$ plant extract. MCC, Matthew's correlation coefficient.

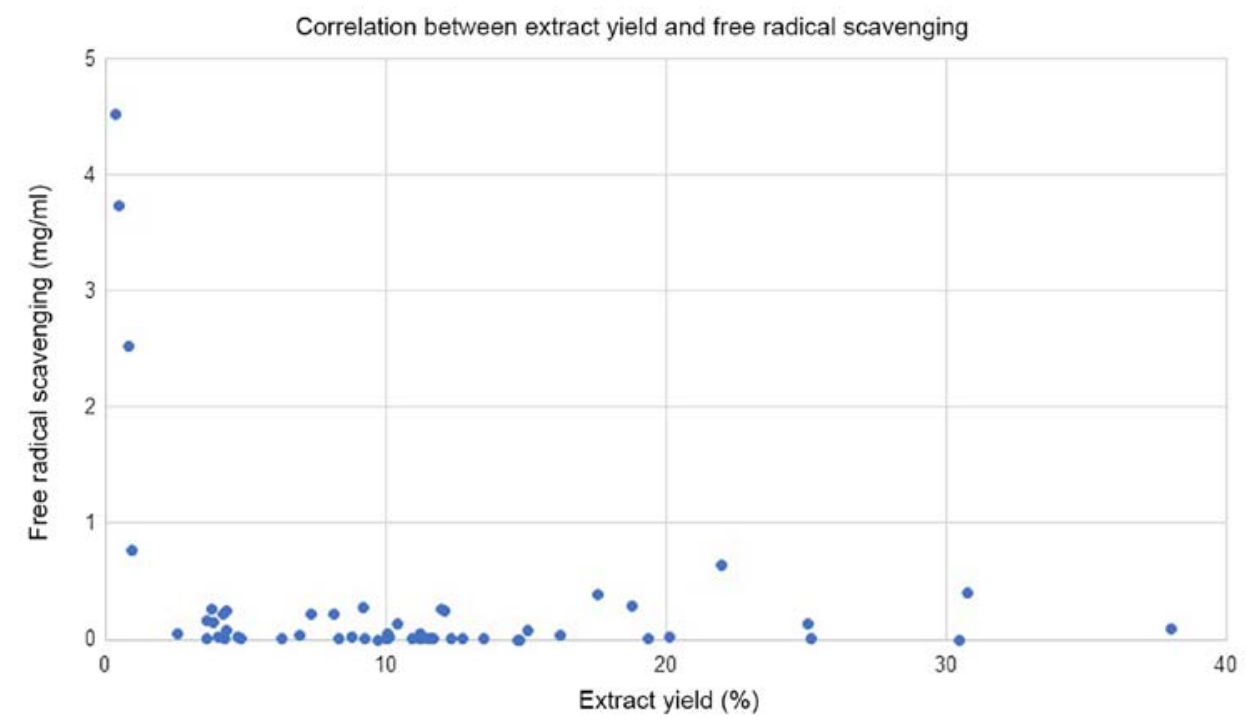

Figure 1. Correlation between $\%$ of yield that was obtained by extraction with methanol and free radical scavenging.

No correlation was detected between the \% of cytotoxicity (using a concentration of $250 \mu \mathrm{g} / \mathrm{ml}$ of plant extract) and the $\mathrm{EC}_{50}$ for free radical scavenging (Fig. 2). Moreover, the correlation between the $\mathrm{EC}_{50}$ for cytotoxicity and the $\mathrm{EC}_{50}$ for free radical scavenging for the nine most cytotoxic plant extracts (Fig. 3) tends slightly toward the negative. The most cytotoxic plant extract (Vitex agnus-castus) showed, by several orders of magnitude, free radical-scavenging less than seven other extracts (Rosmarinus officinalis, Origanum vulgare, Cynara cardunculus, Lippia citriodora, Zingiber officinale, Cinnamomum aromaticum, and Laurus nobilis) out of the nine most cytotoxic plants. The obtained results show that differences in cytotoxic activities among the extracts are not mainly accredited to the level of antioxidants but could also be associated with the inhibitory effects via other signaling pathways.

Figs. 4 and 5 depict the enrichment plot and the receiver operating characteristic (ROC) plot for the cytotoxicity/free radical-scavenging correlation model. It is worth noting that a fully random model should yield an AUC value around 0.5 . The area under the curve (AUC) that was attained for the current model, as shown in Fig. 5, is 0.705, which means that the model is very poor, indicating a very weak correlation between cytotoxicity and free radical scavenging. The enrichment plot that is shown in Fig. 4 illustrates how quickly cytotoxic extracts of plants can be identified when they are sorted according to their free radical scavenging activity. If the enrichment plot of the 


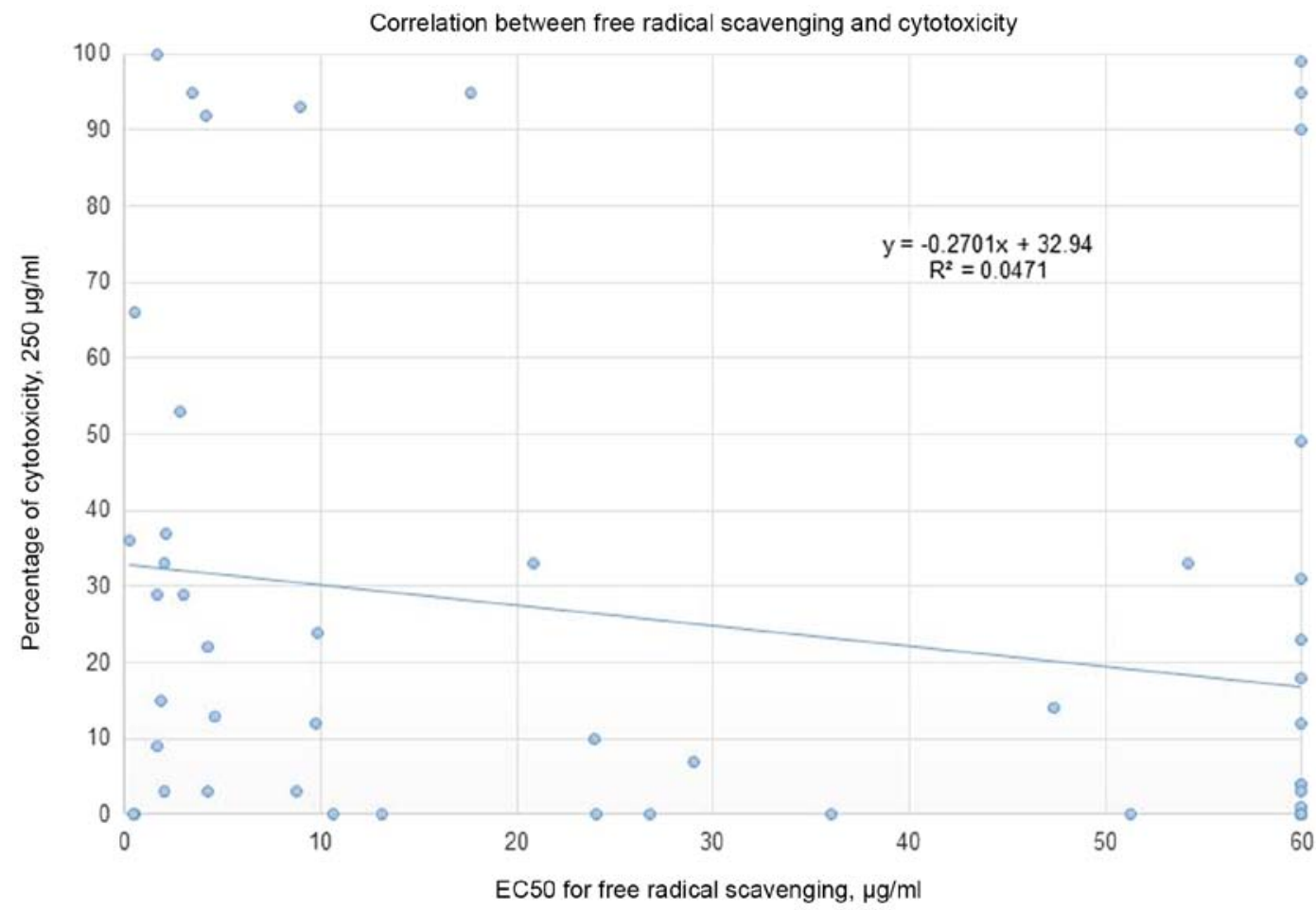

Figure 2. Correlation between the \% of cytotoxicity at a concentration of $250 \mu \mathrm{g} / \mathrm{ml}$ of plant extract and an $\mathrm{EC}_{50}$ for free radical scavenging expressed in units of $\mu \mathrm{g} / \mathrm{ml}$. The $\mathrm{EC}_{50}$ of free radical scavenging for each plant extract, which is $>60 \mu \mathrm{g} / \mathrm{ml}$, was set at $60 \mu \mathrm{g} / \mathrm{ml}$.

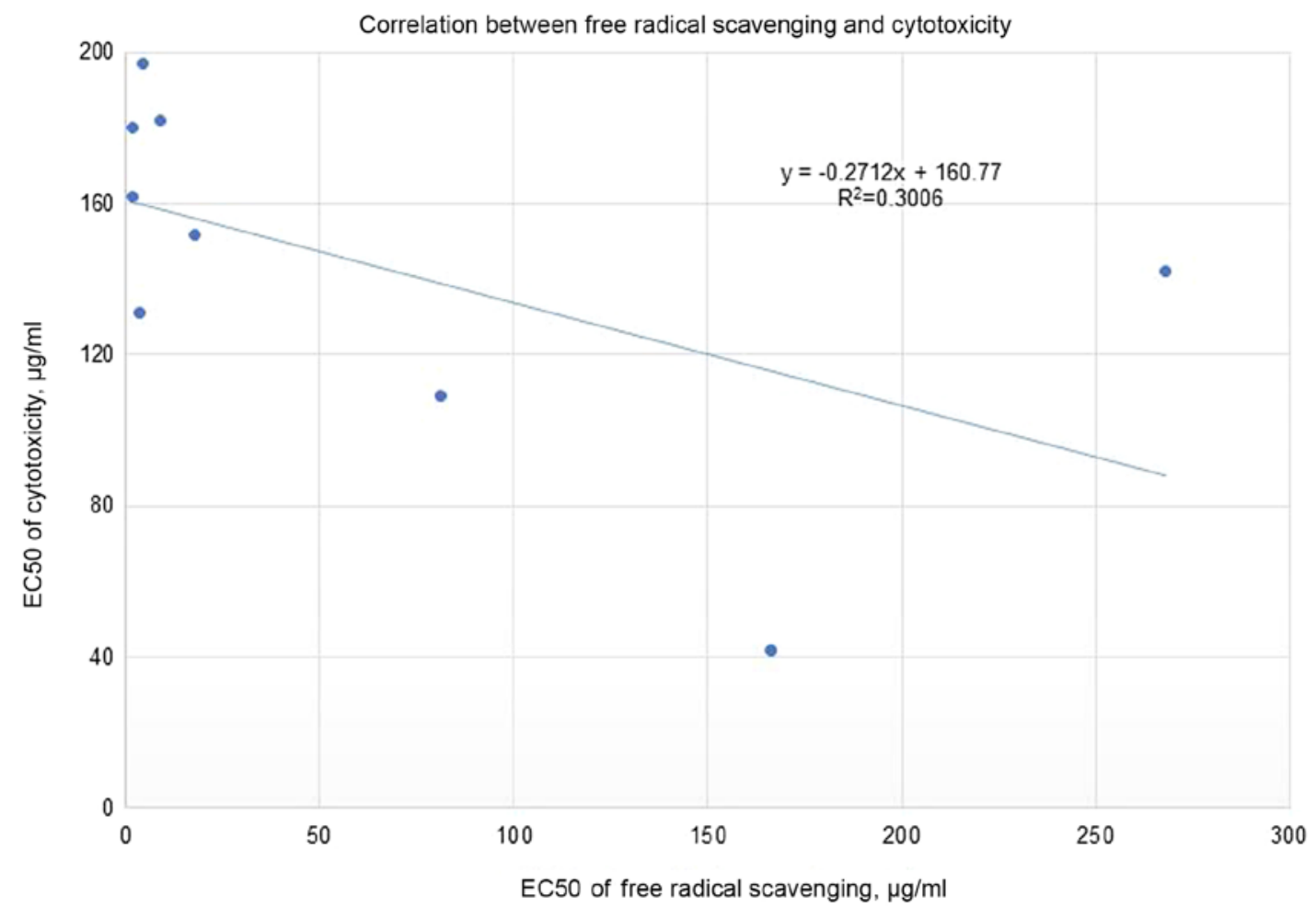

Figure 3. Correlation between the $\mathrm{EC}_{50}$ for cytotoxicity and the $\mathrm{EC}_{50}$ for free radical scavenging for the nine most cytotoxic plant extracts.

proposed model is close to the perfect model, it indicates high prioritization power. A close look reveals that the shape of the figure fits well with the conclusions drawn from the detailed analysis of Table II, which disclosed that plant extracts with an $\mathrm{EC}_{50}$ of free radical scavenging $\leq 10 \mu \mathrm{g} / \mathrm{ml}$ display some degree of enrichment toward more cytotoxicity. At this point, the model line is closer to the experimental line than to the random line.

In mid-October 2018, the electronic database PubMed was searched using the scientific names of the demonstrably cytotoxic plants disclosed herein and the keyword anticancer. Eight out of 


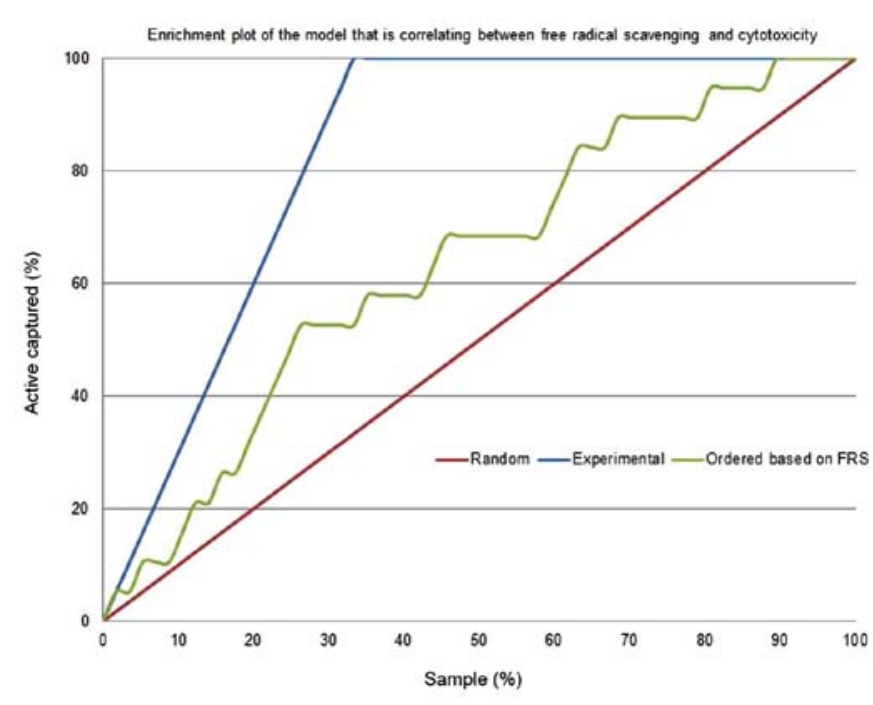

Figure 4. Enrichment plot of the prediction model for the cytotoxicity of the plant extracts, based on their free radical-scavenging activity. FRS, free radical scavenging.

the nine cytotoxic plant extracts were reported to be active against cancer cell lines. As well, half of the eight were reported as active against HepG2, while the rest are reported here for the first time as showing activity against HepG2. Rosmarinus officinalis $(34,35)$ and its components, the phenolic compound rosmarinic acid (36) and the abietane diterpenoid sageone (37), were reported to show anticancer properties, but had not been tested on HepG2. Origanum vulgare (38) and its main constituents (carvacrol, thymol, citral, and limonene) have been tested on HepG2 cell line (liver cancer) and were reported as active against cancer. Cynara cardunculus L. has evidenced anticancer potential (39) on triple-negative breast cancer (TNBC). It highlights the antiproliferative effects of lipophilic extracts from the leaves and florets of $C$. cardunculus L., and of their major constituents, namely cynaropicrin and taraxasteryl acetate, against MDA-MB-231 cells. A review article by Bahramsoltani (40) reported anticancer effects for Lippia citriodora against human colon cancer (HT29) cells; its extract enhances BAX (a pro-apoptotic gene) and reduces the expression level of Bcl-2 (an anti-apoptotic gene). Zingiber officinale extract significantly inhibited the proliferation of HepG2 cells and induced apoptosis (41). Cinnamomum cassia (syn. Cinnamomum aromaticum) extracts were reported to have anticancer activity (42). Laurus nobilis was reported as active against cancer cell lines (43) such as HeLa cells, but its activity on HepG2 had not been tested. Salvia officinalis extracts were confirmed to have cytotoxic effects on HepG2 cells (44). Recently, Kikuchi et al (45). demonstrated that an extract from the ripe fruit of Vitex angus-castus (Vitex), might be a promising anticancer candidate. It was the only scientific report to mention its cytotoxicity, which was tested by its effects on HL-60 cells, but not on HepG2; no phytochemicals were identified as the source of its cytotoxicity. We are currently working on isolating and identifying its bioactive chemical ingredients.

Since reactive oxygen species (ROS) are known to be triggers of various human cancers, and antioxidants or scavengers are used to counteract these dangerous species, we have raised a question regarding the correlation between free radical scavenging and the cytotoxicity of plant extracts. Free radical

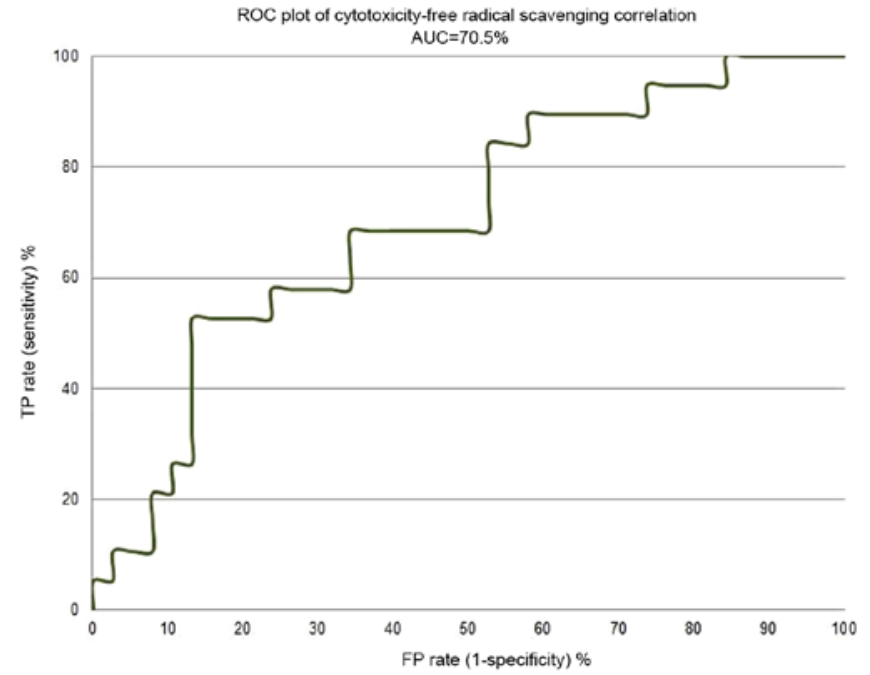

Figure 5. A receiver operating characteristic curve showing the performance of the cytotoxicity/free radical-scavenging correlation model. TP, true positive; FP false positive.

scavenging was assessed by DPPH assay, while cytotoxicity was measured by XTT assay. Nine extracts were found to be cytotoxic with $\mathrm{EC}_{50}$ values of $<250 \mu \mathrm{g} / \mathrm{ml}$, and four others had a high content of antioxidants, with $\mathrm{EC}_{50}$ values of free radical scavenging of $<0.5 \mu \mathrm{g} / \mathrm{ml}$. Upon looking on the results which were obtained from screening fifty-seven plants for their cytotoxic activity, we concluded, from first inspection, that there is no correlation between free radical scavenging and cytotoxicity. However, an in-depth analysis of the results reveals that the extracts of plants that had an $\mathrm{EC}_{50}$ for free radical scavenging $\leq 10 \mu \mathrm{g} / \mathrm{ml}$ exhibited a certain enrichment toward more cytotoxicity (enrichment factor of 1.5). We suggest checking further the validity of the conclusions that are drawn from the current study on other cancer cell-lines, and also by utilizing aqueous or other organic solvents to perform the extraction. The nine active extracts of plants disclosed here could be a source of anticancer hits/lead phytochemicals, worth the effort it would take to isolate and chemically identify them.

\section{Acknowledgements}

Not applicable.

\section{Funding}

This work was partially supported by the Al-Qasemi Research Foundation and the Ministry of Science, Space and Technology, Israel.

\section{Availability of data and materials}

The datasets used and/or analyzed during the current study are available from the corresponding author on reasonable request.

\section{Authors' contributions}

AR conceived the study, designed the experiments, and contributed to writing and editing the manuscript. MF 
interpreted the data and wrote the original manuscript. BAF and IR collected the plants, performed their extraction and the run free radical-scavenging experiments. MS designed and performed the cytotoxicity experiments, interpreted the data and wrote the original draft.

\section{Ethics approval and consent to participate}

Not applicable.

\section{Patient consent for publication}

Not applicable.

\section{Competing interests}

The authors declare that they have no competing interests.

\section{References}

1. Aswad M, Rayan M, Abu-Lafi S, Falah M, Raiyn J, Abdallah Z and Rayan A: Nature is the best source of anti-inflammatory drugs: Indexing natural products for their anti-inflammatory bioactivity. Inflamm Res 67: 67-75, 2018.

2. Frank A, Abu-Lafi S, Adawi A, Schwed JS, Stark H and Rayan A: From medicinal plant extracts to defined chemical compounds targeting the histamine $\mathrm{H} 4$ receptor: Curcuma longa in the treatment of inflammation. Inflamm Res 66: 923-929, 2017.

3. Zaid H, Raiyn J, Osman M, Falah M, Srouji S and Rayan A: In silico modeling techniques for predicting the tertiary structure of human H4 receptor. Front Biosci (Landmark Ed) 21: 597-619, 2016.

4. Zeidan M, Rayan M, Zeidan N, Falah M and Rayan A: Indexing natural products for their potential anti-diabetic activity: Filtering and mapping discriminative physicochemical properties. Molecules 22: E1563, 2017.

5. Sui YB, Liu L, Tian QY, Deng XW, Zhang YQ and Li ZG: A retrospective study of traditional Chinese medicine as an adjunctive therapy for patients with chronic heart failure. Medicine (Baltimore) 97: e11696, 2018

6. Maiti P and Dunbar GL: Use of curcumin, a natural polyphenol for targeting molecular pathways in treating age-related neurodegenerative diseases. Int J Mol Sci 19: E1637, 2018.

7. Masalha M, Rayan M, Adawi A, Abdallah Z and Rayan A: Capturing antibacterial natural products with in silico techniques. Mol Med Rep 18: 763-770, 2018.

8. Kacergius T, Abu-Lafi S, Kirkliauskiene A, Gabe V, Adawi A, Rayan M, Qutob M, Stukas R, Utkus A, Zeidan M and Rayan A: Inhibitory capacity of Rhus coriaria L. extract and its major component methyl gallate on Streptococcus mutans biofilm formation by optical profilometry: Potential applications for oral health. Mol Med Rep 16: 949-956, 2017.

9. Vallejo MJ, Salazar L and Grijalva M: Oxidative stress modulation and ROS-mediated toxicity in cancer: A review on in vitro models for plant-derived compounds. Oxid Med Cell Longev 2017: 4586068, 2017.

10. Chikara S, Nagaprashantha LD, Singhal J, Horne D, Awasthi S and Singhal SS: Oxidative stress and dietary phytochemicals: Role in cancer chemoprevention and treatment. Cancer Lett 413: 122-134, 2018.

11. Gavamukulya Y, Wamunyokoli F and El-Shemy HA: Annona muricata: Is the natural therapy to most disease conditions including cancer growing in our backyard? A systematic review of its research history and future prospects. Asian Pac J Trop Med 10: 835-848, 2017.

12. Kapinova A, Stefanicka P, Kubatka P, Zubor P, Uramova S, Kello M, Mojzis J, Blahutova D, Qaradakhi T, Zulli A, et al: Are plant-based functional foods better choice against cancer than single phytochemicals? A critical review of current breast cancer research. Biomed Pharmacother 96: 1465-1477, 2017.

13. Rayan A, Raiyn J and Falah M: Nature is the best source of anticancer drugs: Indexing natural products for their anticancer bioactivity. PLoS One 12: e0187925, 2017.

14. Tariq A, Sadia S, Pan K, Ullah I, Mussarat S, Sun F, Abiodun OO, Batbaatar A, Li Z, Song D, et al: A systematic review on ethnomedicines of anti-cancer plants. Phytother Res 31: 202-264, 2017.
15. Aggarwal BB and Shishodia S: Molecular targets of dietary agents for prevention and therapy of cancer. Biochem Pharmacol 71: 1397-1421, 2006.

16. Raza A and Sood GK: Hepatocellular carcinoma review: Current treatment, and evidence-based medicine. World J Gastroenterol 20: 4115-4127, 2014.

17. Ali H, Dixit S, Ali D, Alqahtani SM, Alkahtani S and Alarifi S: Isolation and evaluation of anticancer efficacy of stigmasterol in a mouse model of DMBA-induced skin carcinoma. Drug Des Devel Ther 9: 2793-2800, 2015.

18. Ziech D, Franco R, Georgakilas AG, Georgakila S, MalamouMitsi V, Schoneveld O, Pappa A and Panayiotidis MI: The role of reactive oxygen species and oxidative stress in environmental carcinogenesis and biomarker development. Chem Biol Interact 188: 334-339, 2010.

19. Galaris D, Skiada V and Barbouti A: Redox signaling and cancer: The role of 'labile' iron. Cancer Lett 266: 21-29, 2008.

20. Jambunathan S, Bangarusamy D, PadmaPR and Sundaravadivelu S: Cytotoxic activity of the methanolic extract of leaves and rhizomes of Curcuma amada Roxb against breast cancer cell lines. Asian Pac J Trop Med 7S1: S405-S409, 2014.

21. Fuchs-Tarlovsky V: Role of antioxidants in cancer therapy. Nutrition 29: 15-21, 2013.

22. Chua MT, Tung YT and Chang ST: Antioxidant activities of ethanolic extracts from the twigs of Cinnamomum osmophloeum. Bioresour Technol 99: 1918-1925, 2008.

23. Abu-Lafi S, Rayan B, Kadan S, Abu-Lafi M and Rayan A: Anticancer activity and phytochemical composition of wild Gundelia tournefortii. Oncol Lett 17: 713-717, 2019.

24. Hwang YJ, Lee EJ, Kim HR and Hwang KA: In vitro antioxidant and anticancer effects of solvent fractions from Prunella vulgaris var. lilacina. BMC Complement Altern Med 13: 310, 2013.

25. Radomska-Leśniewska DM, Hevelke A, Skopiński $P$, Bałan B, Jóźwiak J, Rokicki D, Skopińska-Różewska E and Białoszewska A: Reactive oxygen species and synthetic antioxidants as angiogenesis modulators: Clinical implications. Pharmacol Rep 68: 462-471, 2016.

26. Boots AW, Haenen GR and Bast A: Health effects of quercetin: From antioxidant to nutraceutical. Eur J Pharmacol 585: 325-337, 2008

27. Kadan S, Rayan M and Rayan A: Anticancer Activity of Anise (Pimpinella anisum L.) Seed Extract. Open Nutraceuticals J 6: $1-5,2013$

28. Zaid H, Rayan A, Said O and Saad B: Cancer treatment by Greco-Arab and Islamic herbal medicine. Open Nutraceuticals J 3: 203-213, 2010.

29. Uttara B, Singh AV, Zamboni P and Mahajan RT: Oxidative stress and neurodegenerative diseases: A review of upstream and downstream antioxidant therapeutic options. Curr Neuropharmacol 7: 65-74, 2009.

30. Perrone S, Santacroce A, Longini M, Proietti F, Bazzini F and Buonocore G: The free radical diseases of prematurity: From cellular mechanisms to bedside. Oxid Med Cell Longev 2018: $7483062,2018$.

31. Valko M, Leibfritz D, Moncol J, Cronin MT, Mazur M and Telser J: Free radicals and antioxidants in normal physiological functions and human disease. Int J Biochem Cell Biol 39: 44-84, 2007.

32. Abu-Lafi S, Rayan M, Masalha M, Abu-Farich B, Al-Jaas H, Abu-Lafi $M$ and Rayan A: Phytochemical composition and biological activities of wild Scolymus maculatus L. Medicines (Basel) 6: E53, 2019.

33. Masalha M, Abu-Lafi S, Abu-Farich B, Rayan M, Issa N, Zeidan $\mathrm{M}$ and Rayan A: A new approach for indexing honey for its heath/medicinal benefits: Visualization of the concept by indexing based on antioxidant and antibacterial activities. Medicines (Basel) 5: E135, 2018.

34. Moore J, Yousef M and Tsiani E: Anticancer effects of rosemary (Rosmarinus officinalis L.) extract and rosemary extract polyphenols. Nutrients 8: E731, 2016.

35. Gonzalez-Vallinas M, Reglero G and Ramirez de Molina A: Rosemary (Rosmarinus officinalis L.) extract as a potential complementary agent in anticancer therapy. Nutr Cancer 67: 1221-1229, 2015.

36. Swamy MK, Sinniah UR and Ghasemzadeh A: Anticancer potential of rosmarinic acid and its improved production through biotechnological interventions and functional genomics. Appl Microbiol Biotechnol 102: 7775-7793, 2018.

37. Shrestha S, Song YW, Kim H, Lee DS and Cho SK: Sageone, a diterpene from Rosmarinus officinalis, synergizes with cisplatin cytotoxicity in SNU-1 human gastric cancer cells. Phytomedicine 23: 1671-1679, 2016. 
38. Elshafie HS, Armentano MF, Carmosino M, Bufo SA, De Feo V and Camele I: Cytotoxic activity of Origanum Vulgare L. on hepatocellular carcinoma cell line HepG2 and evaluation of its biological activity. Molecules 22: E1435, 2017.

39. Ramos PA, Guerra AR, Guerreiro O, Santos SA, Oliveira H, Freire CS, Silvestre AJ and Duarte MF: Antiproliferative Effects of Cynara cardunculus L. var. altilis (DC) lipophilic extracts. Int J Mol Sci 18: E63, 2016.

40. Bahramsoltani R, Rostamiasrabadi P, Shahpiri Z, Marques AM, Rahimi R and Farzaei MH: Aloysia citrodora Palau (Lemon verbena): A review of phytochemistry and pharmacology. J Ethnopharmacol 222: 34-51, 2018.

41. Elkady AI, Abu-Zinadah OA and Hussein R: Crude flavonoid extract of medicinal herb Zingibar officinale inhibits proliferation and induces apoptosis in hepatocellular carcinoma cells. Oncol Res 25: 897-912, 2017.

42. Lin CY, Hsieh YH, Yang SF, Chu SC, Chen PN and Hsieh YS: Cinnamomum cassia extracts reverses TGF- $\beta 1$-induced epithelial-mesenchymal transition in human lung adenocarcinoma cells and suppresses tumor growth in vivo. Environ Toxicol 32: $1878-1887,2017$.
43. Berrington D and Lall N: Anticancer activity of certain herbs and spices on the cervical epithelial carcinoma (HeLa) cell line. Evid Based Complement Alternat Med 2012: 564927, 2012.

44. Jiang Y,Zhang L and Rupasinghe HP: Antiproliferative effects of extracts from Salvia officinalis L. and Saliva miltiorrhiza Bunge on hepatocellular carcinoma cells. Biomed Pharmacother 85: 57-67, 2017.

45. Kikuchi H, Yuan B, Nishimura Y, Imai M, Furutani R, Kamoi S, Seno M, Fukushima S, Hazama S, Hirobe C, et al: Cytotoxicity of Vitex agnus-castus fruit extract and its major component, casticin, correlates with differentiation status in leukemia cell lines. Int J Oncol 43: 1976-1984, 2013.

This work is licensed under a Creative Commons Attribution-NonCommercial-NoDerivatives 4.0 International (CC BY-NC-ND 4.0) License. 